\title{
Ways to Improve the Management of The Economic Security of Travel Companies
}

\author{
Maryna CHORNA ${ }^{1}$, Marta BARNA ${ }^{2}$, Tetiana ANDROSOVA ${ }^{3}$, \\ Nataliia USHAKOVA ${ }^{4}$ And Iryna TUCHKOVSKA ${ }^{5}$ \\ ${ }^{1,3,4}$ Kharkov State University of Food Technology and Trade, Ukraine \\ 2,5 Lviv University of Trade and Economics, Ukraine
}

Correspondence should be addressed to: Maryna CHORNA; marynachorna@yahoo.com

Received date: 22 April 2019; Accepted date: 16 July 2019; Published date: 28 August 2019

Copyright (C) 2019. Maryna CHORNA, Marta BARNA, Tetiana ANDROSOVA, Nataliia USHAKOVA

And Iryna TUCHKOVSKA. Distributed under Creative Commons CC-BY 4.0

\begin{abstract}
The methodological approaches to the assessment of the economic security of a travel company on the basis of quantitative and qualitative methods for assessing the components of the company's external and internal environment (PEST analysis) and statistical modeling were improved which allows increasing the objectivity of management decisions taking into account the peculiarities of the functioning of travel companies in Bulgaria. The process of the economic security management of a travel company, containing relevant stages and controls within the institutional, organizational, economic and informationalmotivational components was improved, which, unlike the existing ones, makes it possible to adapt to the needs of the market and the requirements of current legislation, as well as to increase the scientific soundness of making management decisions. The practical significance of the obtained results lies in the fact that scientific developments and proposals of the work was brought to the level of theoretical and methodological generalizations, methodological and practical recommendations for the economic security management of travel companies.
\end{abstract}

Keywords: travel companies, security management, strategic analysis, tourist product, seasonal fluctuations in demand

Cite this Article as: Maryna CHORNA, Marta BARNA, Tetiana ANDROSOVA, Nataliia USHAKOVA And Iryna TUCHKOVSKA (2019)," Ways to Improve the Management of The Economic Security of Travel Companies", IBIMA Business Review, Vol. 2019 (2019), Article ID 126670, DOI: 10.5171/2019.126670 


\section{Introduction}

The peculiarity of the activities of travel companies is the presence of various risk factors that have a direct impact, on the one hand, on tourists, and on the other - on the activities of travel companies. Features of the management of travel company and economic security are determined by its financial condition and the specific characteristics of the tourist product and tourist services, such as: inability to feel it before consumption; continuity of production and consumption in the provision of tourist services, since production occurs in parallel with the consumption; dependence on the time and place of receiving the tourist product (service); impossibility of preservation; high elasticity of demand for a tourist product by income and price; seasonal fluctuations in demand for tourist services; the subjectivity of assessing the quality of tourist services; tourist product is created by the efforts of many companies, each of which has its own specifics, methods of work and the like.

That is, there is a need for a specific management mechanism that would allow the best possible methods, in terms of goals, to continuously monitor factors and analyze their impact on the economic security of a tourist operator for consideration when making management decisions. Such a mechanism is the system of economic security management.

\section{Literature Survey}

The economic security of a travel company plays an important role not only in the current, but also in its future activities, and it also affects the economic security of the whole country, since each company is a key structural element of the state economy (Drobyazko, S., Hryhoruk, I., Pavlova, H., Volchanska, L., \& Sergiychuk, S. (2019), Hilorme, T., Perevozova, I., Shpak, L., Mokhnenko, A. \& Korovchuk, Yu. (2019)).

In a crisis, the greatest danger to a travel company is the destruction of its potential (production, technological, scientific, technical and personnel) as the main factor in the life of the company and its capabilities (Radović, V., \& Arabska, E. (2016)).

In connection with the development of tourism, its favorable natural-resource, historical and cultural potential, as well as the heightened interest of scientists in finding ways to work effectively for travel companies, the issues of clarifying their level of functioning and developing ways to ensure economic security are of current interest.

A travel company has technical, commercial, intellectual information, the use of which by competitors can weaken the position of the company on the study market and lead to loss of profits (Valdés, J. (2018)).

The problem of ensuring the economic security of travel companies remains the subject of sharp scientific discussions, which indicates the complexity of this concept and the ambiguity of interpretation (Augutis, J., Krikštolaitis, R., Martišauskas, L., Pečiulytė, S., \& Žutautaitè, I. (2017)). After conducting a semantic analysis of the economic security sources of a travel company, the following study fields can be distinguished: implementation and protection of economic interests (Mathew, P. V., \& Sreejesh, S. (2017)), condition of resource efficiency (Rivera, M., Croes, R., \& Lee, S. H. (2016)), protection against economic crimes (Toneva, P. I. (2017)), competitive advantages (Strezov, V., Evans, A., \& Evans, T. J. (2017)), internal and external threats resistance (Smith, T. G., Stillman, S., \& Craig, S. (2016)). That is, when forming the system of economic security of a travel company, it is necessary to consider all five directions.

\section{Methods}

In the process of study, general scientific and special methods of scientific knowledge were used, namely: critical analysis, scientific abstraction and 
generalization of the scientific experience of modern theoretical studies, empirical method (in determining directions for improving the conceptual apparatus, studying the theoretical foundations and scientific approaches to the economic security management of travel companies); method of analysis and synthesis and theoretical generalization (in determining scientific approaches to understanding the essence, role and place of economic security in the activities of travel companies); strategic analysis, in particular, PEST analysis.

In order to study the indirect impact environment, the article contains a PEST analysis. PEST analysis is a convenient method for the macroenvironment analysis (external environment) of a tourism sector. PEST-analysis techniques are often used to assess key industry trends in the industry, and PEST-analysis results can be used to determine a list of threats and opportunities when compiling a company SWOT analysis (Hilorme, T., Shurpenkova, R., Kundrya-Vysotska, O., Sarakhman, O., \& Lyzunova, 0. (2019)). PEST-analysis is a tool for long-term strategic planning and is prepared for 3-5 years in advance, with annual updates. It can be made in the form of a matrix of 4 quadrants or in tabular form. The whole process of PEST analysis can be divided into the following stages: determination of factors that may affect the sales and profits of the company; collection of information on the dynamics and nature of changes in each factor; analysis of the significance and degree of influence of each factor; summary table compiling of the PEST analysis.

\section{Results}

From the point of view of the theoretical model and means of influencing the subject of management, the economic security management of a tourist operator is a specific direction of management, which has specific content, goals, objectives and organizational and economic means of their implementation. Accordingly, the methodology, principles, process and management functions of the economic security of a tourist operator derive from the basic principles of management skills.

The common (core) management functions are goal definition, planning, organization, motivation and control, analysis.

The universality of these functions is emphasized by their repeatability or cyclical nature in management processes; therefore, these functions are often referred to as typical elements of the management cycle. The presence of common functions determines the fundamental unity of the structure of the management process in enterprises, regardless of their industry sector.

The main goal of the economic security management system of a tourist operator is to ensure its viability and sustainable functioning in the event of any organizational, economic, political, social and other changes in its internal and external environment. In order to achieve it, the management of the economic security of the tour operator should be aimed at:

- neutralization (overcoming) or limiting the number of negative (destructive) factors influencing the economic security of a travel company by forming protection against them;

- use of positive external factors of influence to increase and implement economic support, economic independence and economic security of the enterprise;

- reproduction and increasing of economic support, economic independence and economic security of the enterprise - the economic security of a tourist operator on the basis of the development of its top characteristics, its market-product and spatial-temporal adaptation to changes in the external environment;

- ensuring the flexibility of management actions and decisions - their synchronization with the dynamics of the negative and positive factors of economic security in a particular market.

Under these conditions, from the perspective of the process approach, the economic security management of a tourist operator is the process of implementing a certain set of managerial functions - 
defining goals, planning, organizing, motivating and controlling activities to create economic security and ensure the vital activities of the tour operator as a subject of economic activity.

At the same time, these goals do not always agree with the traditional financial and economic goals of the operator - an increase in operator incomes; increase profits; providing a certain amount of income or profit, and the like. Therefore, in the process of setting goals one should not only define all the goals, but also, as more possible, coordinate them with each other.

The most important feature of planning as a function of the economic security management of a tourist operator is that, along with the development of strategy and tactics, as well as a plan of action to achieve the goals, it requires the identification of a potential level of economic security.

Significant differences are typical for the monitoring, which is the final function of the management cycle. In general, it consists in observing the course of production processes and identifying deviations from them (the ratio of the actual results achieved with the planned ones). With its help, an assessment of performance results is achieved. Regarding the management of the economic security of the tourist operator, this function is aimed at identifying changes in the external and internal environment of the operator, their real or possible impact on the level of economic security, timely response to these changes. In the process of this function implementation, a system of indicators is formed that significantly affect the level of economic security of the tourist operator, the frequency of their definition, the amount of information, and the like.

Therefore, there is a need to study the management of economic security of travel companies, to search for fundamentally new approaches and solutions for improving the organization of their activities, the implementation of which would level the destabilizing effect of threats to economic security, create prerequisites for the formation of a mechanism of ensuring it in the long term and contribute to the growth of companies profits and their attractiveness. In this regard, it is advisable for each travel company to focus on maintaining a normal business rhythm and preventing material or financial damage, preventing unauthorized access to official information and destruction of computer databases, and the like.

Travel companies that act as travel organizers and serve tourists are the basis of organizational and economic relations in the tourism industry in Bulgaria. Today, travel company services in organizing travel and tourist services are of particular not only economic but also social significance.

Since the tourism market in Bulgaria is dynamically developing and changing, this not only contributes to the emergence of new opportunities for entrepreneurial activity in this sector of the economy, but also constantly creates new institutional problems in the provision of study to the wide segments of society.

The complexity of travel companies activity in modern conditions is due to a number of problems associated with a high degree of uncertainty due to seasonality and instability of demand for tourism products and services, significant social stratification of society, variability of social and political orientations of tourism development, increasing of the competitive environment dynamics in the tourism market, complication of the political situation in the world due to local military conflicts, terrorist acts, natural disasters.

All this confirms the fact that it is useful to have an interest in the study of the management of the economic security of travel companies, which play an important role in the development of the tourism sector both in individual territories, regions, and the country as a whole.

The management of economic security of travel companies necessitates travel companies to protect their potential, material and non-material resources, that is, to develop their own methodological 
tools for ensuring economic security, which is to develop measures aimed at preventing damage from various negative impacts on their activities.

The economic security of a travel company is a function of the economic condition of the company, the degree of solution of the personnel issue and the situation in the external environment; function of economic, social, environmental, political and other components (Ghaderi, Z., Saboori, B., \& Khoshkam, M. (2017)). The employees of a travel company cannot physically influence all factors affecting economic security, but they can carry out measures that enhance the economic security of a travel company, namely, improve the quality of services provided, tourism products, tourist recreation conditions, and the like.

The economic security of a travel company is a complex dynamic economic category which is constantly changing and is influenced by a large number of socioeconomic, historical, political, cultural, technological and other factors, which require the use of sometimes diverse indicators in the process of assessing its wide range.

Considering that the economic security of a travel company characterizes its level of viability and possibility of effective functioning not only today, but also over a long period of time in the future, it becomes necessary to determine the level of threats, in particular, the justification of the limit value, above which the indicator under study provides proper condition of all components of the economic security of a company.

It should be noted that the contradictions arising today between the growing needs of the population in study and the possibilities for satisfying the tourism industry, between changes in the competitive situation and insufficient competence of personnel in various fields of tourism activity - management, economic, environmental, legal, personnel, determine the need to improve personnel training and to create a basic education system in tourism.

We consider that the main tasks of modern professional education in the field of tourism are: provision of fundamental scientific, professional and practical training in the field of tourist activities; obtaining by students of knowledge and skills of educational qualification levels in accordance with their vocation, interests and abilities; improvement of scientific and professional training of personnel in the tourism sector.

In our opinion, in order to ensure the high competitiveness of the tourist product in the domestic and international tourist services markets, specialists with social, humanitarian, cultural, historical, legal, aesthetic, recreational, environmental, economic and other aspects of knowledge, skills in the field of information technology, foreign languages, geography and organizational and management activities need a high level of training.

In order to achieve a high level of professional training, it is advisable to study and apply the world experience of theoretical and practical professional training of future specialists in the tourism sector, in particular, the experience of the Cornwall College and the Bournemouth University in the United Kingdom, the Swiss Hotel Management School (SHMS) and the Ecole hôtelière de Lausanne (EHL), the International hotel and tourism management school in Paris, the experience of the Johnson \& Wales University in the USA (Dorondel, S., \& Şerban, S. (2018)).

The financial component takes a special place in the study of the economic security of a company, since in market economy conditions, finance is the "driving force" of a travel company, as of every business entity, and its weakening is demonstrated by: decrease in liquidity of the company; increase in accounts payable and receivable; decrease in financial stability, etc. (Drobyazko, S. (2018a)). 
The legal component of the economic security of a travel company is in compliance with the requirements of current legislation in the implementation of tourism activities.

The technological component of the economic security of a travel company is intended to analyze the market of technologies used in the provision of study of a similar profile by other travel companies, taking into account the degree of compliance of the technologies used by the company with the best world analogues with optimal costs.

The information component is intended to provide effective information and analytical support of all economic activities of a travel company.

Persons who organize the exploitation of tourism resources are obliged to comply with the requirements of environmental protection and protection of cultural heritage, as well as to take measures to ensure the minimization or cessation of harmful effects on the environment and socio-cultural environment and to compensate for the losses caused to them.

The economic security of travel company takes into account the possible destructive anthropogenic impact on natural tourism resources and facilities. At the same time, the economic security of tourists is central to the study of methods of organizing trips of various types of active tourism, so it is necessarily associated with travel insurance (Hilorme, T., Zamazii, O., Judina, O., Korolenko, R. \& Melnikova, Yu. (2019)). Without the functioning of a reliable system of insurance of tourism activities and tourists in particular, it is impossible to achieve a high level of competitiveness in the international market of tourism services and ensure the sustainable development of travel companies. The insurance process determines the quality of services and also creates an image of the tourism industry as a whole.
The task of strategic management is to provide such interaction of a travel company with the external environment, which will enable it to maintain the potential at the level necessary to achieve its goals, and survive in the long term. In order to determine the strategy of behavior of a travel company and implement it, management must have an in-depth understanding of the external environment, its development trends and the place that the company occupies in it (Carranza, M. E. (2017)). At the same time, the external environment is studied, first of all, in order to identify the dangers and potential opportunities that a travel company must take into account when defining and achieving its goals (Costea, M., Hapenciuc, C. V., \& Arionesei, G. (2016)).

The main criteria for assessing the reliability and effectiveness of the economic security of a travel company should be: ensuring stable operation of a company; preservation of monetary and material values; ensuring of stable profit; prevention of crisis and emergency situations; timely detection, prevention and neutralization of real and potential internal and external threats to national interests in the field of tourism in order to create safe living conditions for tourists in the provision of tourism services.

Since the subjects of economic security of a travel company can be persons and structural units operating directly in the company (internal subjects) and organizations and officials who are not a part of a travel company (external subjects), the security of all subjects of the economic security of a travel company in combination with business processes of a travel company ensures the continuity of the technology of tourism services provision.

Tables 1 presents the PEST-analysis of tourism activities in Bulgaria according to the author's study. 
Table 1: Summary table of PEST- analysis of tourism activities in Bulgaria

\begin{tabular}{|c|c|c|c|}
\hline \multicolumn{2}{|l|}{ POLITICAL FACTORS } & \multicolumn{2}{|l|}{ ECONOMIC FACTORS } \\
\hline Factor & Weight & Factor & Weight \\
\hline $\begin{array}{l}\text { Probability of military action in } \\
\text { the country }\end{array}$ & 0.24 & Inflation rate and interest rates & 0.25 \\
\hline Visa regimes between countries & 0.18 & Income level of population & 0.24 \\
\hline $\begin{array}{lll}\begin{array}{l}\text { Antimonopoly } \\
\text { legislation }\end{array} & \text { and } & \text { labor } \\
\end{array}$ & 0.12 & Rates of major currencies & 0.20 \\
\hline Tax policy (tariffs and privileges) & 0.11 & $\begin{array}{l}\begin{array}{l}\text { Price increase for transport services, } \\
\text { communication }\end{array} \\
\end{array}$ & 0.09 \\
\hline $\begin{array}{l}\text { Bureaucratization and level of } \\
\text { corruption }\end{array}$ & 0.07 & $\begin{array}{l}\text { Level of business and business environment } \\
\text { development }\end{array}$ & 0.09 \\
\hline $\begin{array}{l}\text { Trends in regulation or } \\
\text { deregulation of tourism industry }\end{array}$ & 0.07 & $\begin{array}{l}\text { Unemployment rate, wage rate and paying } \\
\text { conditions }\end{array}$ & 0.05 \\
\hline $\begin{array}{l}\text { Freedom of information and } \\
\text { media independence }\end{array}$ & 0.03 & $\begin{array}{l}\text { Degree of globalization and openness of the } \\
\text { economy }\end{array}$ & 0.03 \\
\hline \multicolumn{2}{|c|}{ SOCIAL AND CULTURAL FACTORS } & \multicolumn{2}{|l|}{ TECHNICAL AND TECHNOLOGICAL FACTORS } \\
\hline Factor & Weight & Factor & Weight \\
\hline $\begin{array}{l}\text { Attitude to work, career, leisure } \\
\text { and retirement }\end{array}$ & 0.22 & Access to the latest information technologies & 0,23 \\
\hline $\begin{array}{lll}\begin{array}{l}\text { Lifestyle and habits of } \\
\text { consumption }\end{array} & & \\
\end{array}$ & 0.20 & $\begin{array}{l}\text { Development and penetration of the Internet, } \\
\text { development of mobile devices }\end{array}$ & 0,19 \\
\hline Health care and education level & 0.19 & Introduction of e-commerce system & 0,18 \\
\hline $\begin{array}{l}\text { Requirements to service quality } \\
\text { and service level }\end{array}$ & 0.14 & \multirow[t]{6}{*}{$\begin{array}{l}\text { Degree of use, introduction and transfer of } \\
\text { information technology }\end{array}$} & \multirow{6}{*}{0,13} \\
\hline Population growth rates & 0.13 & & \\
\hline Size and structure of family & 0.07 & & \\
\hline $\begin{array}{l}\text { Social stratification in society, } \\
\text { minorities }\end{array}$ & 0.06 & & \\
\hline $\begin{array}{l}\begin{array}{l}\text { Development of religion and } \\
\text { other beliefs }\end{array} \\
\end{array}$ & 0.03 & & \\
\hline $\begin{array}{lr}\text { Attitude to } & \text { natural } \begin{array}{r}\text { and } \\
\text { environmentally } \\
\text { products }\end{array} \\
\end{array}$ & 00.02 & & \\
\hline
\end{tabular}

During the analysis of technological factors, it is necessary to pay attention to 4 parameters: possible changes in key technologies used in the market (innovations in equipment, materials, business models and business practices); impact of the Internet on market development; impact of mobile technology on market development; innovations in information technologies that allow you to compete more effectively in the market. The analysis of the technological component allows us to foresee the opportunities associated with the development of science and technology, to switch to the production and sale of a technologically promising product in a timely manner, to predict the moment of abandonment of the technology used.

When conducting a PEST analysis of tourism activities in Bulgaria, 4 groups of factors were identified and the weights of subfactors were determined by experts. In group 1 "POLITICAL FACTORS" were assigned: probability of military action in the country $(0.24)$, visa regimes between countries (0.18), antimonopoly and labor legislation (0.12), tax policy (tariffs and privileges) (0.11), bureaucratization and 
level of corruption (0.07), trends in regulation or deregulation of tourism industry (0.07), freedom of information and media independence (0.03).

In group 2 "ECONOMIC FACTORS" were assigned: inflation rate and interest rates $(0.25)$, income level of population $(0.24)$, rates of major currencies (0.2), price increase for transport services, communication (0.09), level of business and business environment development (0.05), degree of globalization and openness of the economy (0.03), unemployment rate, wage rate and paying conditions (0.05).

In group 3 "SOCIAL AND CULTURAL FACTORS" were assigned: attitude to work, career, leisure and retirement (0.22), lifestyle and habits of consumption (0.20), health care and education level (0.19), requirements to service quality and service level (0.14), population growth rates $(0.13)$, size and structure of family (0.07), social stratification in society, minorities (0.06), development of religion and other beliefs (0.03), attitude to natural and environmentally friendly products $(0.02)$.

In group 4 "TECHNOLOGICAL FACTORS" were assigned: access to the latest information technologies (0.23), development and penetration of the Internet, development of mobile devices (0.19), introduction of e-commerce system (0.18), degree of use, introduction and transfer of information technology (0.13).

\section{Discussion}

In the final form of the analysis of external factors influencing the economic security of a travel company using the PEST-analysis method, the recommended actions of a company are given on the example of tourist activities in Bulgaria depending on the influence of external factors. At the same time, each external sub-factor of economic security of a travel company can be depending on the behavior (increase or decrease) of both a stimulant and a disincentive. Analyzing the external environment of tourism activities in Bulgaria, it can be stated that today travel company has all the possibilities for the development of its activities. Social, economic and political factors cause the most significant influence.

The management of the economic security of a travel company is the process of implementation of the functional components of economic security in order to prevent possible losses and to achieve the maximum level of economic security now and in the future.

Activities to ensure the economic security of a travel company should include: justification of the level of acceptable risk in making management decisions; development of a strategy and tactics for doing business, which will minimize economic risk and ensure economic security; protection of material, financial, personnel and information resources of travel company from the possible negative impact of factors and threats.

Both external and internal risks can directly affect the scope and quality of services provided, as well as changes in their structure. In contrast to variable costs, which change in proportion to the scope of services rendered, the growth of fixed costs increases the risk of instability of travel company.

In this regard, it is necessary to use an integrated approach based on risk theory as an active position, which involves the prediction of further events, rather than a passive risk response, because this approach provides more opportunities to avoid threats and limits the risk of their occurrence.

Implementation of the decisions made is provided through practical methods of risk management, that is, through: defining the main tasks and functions related to risk management, planning measures to reduce risks, determining the forms of their financing; rational combination of all elements of the management system: distribution of tasks by management level, formation of divisions (training of specialists) in risk management, distribution of rights, duties and 
authorities to ensure effective risk management; information flow formation and risk management support.

In order to create an effective risk management system in a travel company, it is necessary to put in place certain organizational efforts, attract additional financial and other resources (Drobyazko, S. (2018b)).

\section{Conclusion}

The main objective of the economic security management of the enterprise is to ensure its stable and maximum efficient operation and high development potential in the future.

The subjects of tourist activities in accordance with the law should develop specific measures to ensure the safety of tourists, sightseers involved in tourist travels, hikes, competitions, prevention of injuries and accidents and are responsible for their implementation.

The territory of Bulgaria is an excellent base for the development of a wide variety of types and forms of tourism and recreation. Objectively assessing the tourist and recreational opportunities of Bulgaria, we can conclude that the region has prerequisites for the long-term development of cultural, educational, health and fitness, ski, natural and educational, scientific and educational, religious, hunting, rural, ecological, water, ethnic, sports and health, business, leisure and entertainment types of tourism. Some factors inhibit the development of tourism and sanatorium-and-health-resort sectors of the region, the solution of which will increase the sales of tourism and sanatorium-and-health-resort services. The number of tourists and healthy people will contribute to the development of tourism and recreation and health improving facilities, namely: unsatisfactory condition of roads and access roads to the objects of tourist and resort attendance; insufficient use of transport facilities for the transportation of tourist flows; inefficient use of tourist and recreational opportunities in areas of the region and rural areas; vague image of Bulgaria in the tourist market; low level of development of tourist and recreational infrastructure; incompatibility of places of residence with international standards; lack of access to many tourist and recreational facilities; lack of road signs and tourist information signs; insufficient number of places for short rest along the roads; unsatisfactory condition of the monuments of historical and architectural heritage; imperfection of the legislative and regulatory framework in the field of tourism and the like.

\section{References}

1. Augutis, J., Krikštolaitis, R., Martišauskas, L., Pečiulytè, S., \& Žutautaitè, I. (2017). Integrated energy security assessment. Energy, 138, 890-901. URL: https://www.sciencedirect.com/science/a rticle/abs/pii/S0360544217312914

2. Carranza, M. E. (2017). South American Free Trade Area or Free Trade Area of the Americas?: Open Regionalism and the Future of Regional Economic Integration in South America: Routledge. URL: https://www.taylorfrancis.com/books/97 $\underline{81351753395}$

3. Costea, M., Hapenciuc, C. V., \& Arionesei, G. (2016). Romania versus Bulgaria: A short analysis of the competitiveness of seaside tourism. In $C B U$ International Conference Proceedings...(Vol. 4, p. 471). Central Bohemia University. URL:

https://search.proquest.com/openview/d2 55bc10a3b0ea5ddf9178546aa068f0/1?pqorigsite $=$ gscholar $\& \mathrm{cbl}=2045748$

4. Dorondel, S., \& Şerban, S. (2018). Dissuading the state: food security, peasant resistance and environmental concerns in rural Bulgaria.Canadian Journal of Development Studies/Revue canadienne d'études du développement, 1-16. URL: https://www.tandfonline.com/doi/abs/10. $\underline{1080 / 02255189.2018 .1498326}$

5. Drobyazko, S. (2018a). Accounting management of enterprises' own of in the conditions of legislative changes. Economics and Finance, 10, 4-11. URL: 
http://ecofin.at.ua/maket_ehkonomika_i_fi nansy_06_2018.pdf

6. Drobyazko, S. (2018b). Features of tourism services accounting structuring in the information-oriented society. Economics and Finance, Volume, 6, 44-49. URL:

http://ecofin.at.ua/maket ehkonomika i fi nansy_10_2018.pdf

7. Drobyazko, S., Hryhoruk, I., Pavlova, H., Volchanska, L., \& Sergiychuk, S. (2019). Entrepreneurship Innovation Model for Telecommunications Enterprises. Volume 22, Issue 2, 2019. URL: https://www.abacademies.org/articles/en trepreneurship-innovation-model-fortelecommunications-enterprises-8097.html

8. Ghaderi, Z., Saboori, B., \& Khoshkam, M. (2017). Does security matter in tourism demand? Current Issues in Tourism, 20(6), 552-565.

URL:

https://www.tandfonline.com/doi/abs/10. $\underline{1080 / 13683500.2016 .1161603}$

9. Hilorme, T., Perevozova, I., Shpak, L., Mokhnenko, A. \& Korovchuk, Yu. (2019). Human Capital Cost Accounting in the Company Management System. Academy of Accounting and Financial Studies Journal. Volume 23, Special Issue 2, 2019. URL: https://www.abacademies.org/articles/Hu man-Capital-Cost-Accounting-in-theCompany-Management-System-15282635-23-SI-2-415.pdf

10. Hilorme, T., Shurpenkova, R., KundryaVysotska, O., Sarakhman, O., \& Lyzunova, 0. (2019). Model of energy saving forecasting in entrepreneurship. Journal of Entrepreneurship Education. Volume 22, Special Issue $1 S$ URL: https://www.abacademies.org/articles/m odel-of-energy-saving-forecasting-inentrepreneurship-7994.html

11. Hilorme, T., Zamazii, O., Judina, 0., Korolenko, R. \& Melnikova, Yu. (2019). Formation of risk mitigating strategies for the implementation of projects of energy saving technologies. Academy of Strategic Management Journal. Volume 18, Issue 3. URL:
https://www.abacademies.org/articles/Fo rmation-of-risk-mitigating-strategies-forthe-implementation-of-projects-19396104-18-3-364.pdf

12. Mathew, P. V., \& Sreejesh, S. (2017). Impact of responsible tourism on destination sustainability and quality of life of community in tourism destinations. Journal of Hospitality and Tourism Management, 31, 83-89. URL: https://www.sciencedirect.com/science/a rticle/abs/pii/S1447677015300474

13. Radović, V., \& Arabska, E. (2016). Why should security aspects be more seriously considered in development of Serbian tourism industry?. TIMS. Acta, 10(1), 71-80. URL:

http://scindeks.ceon.rs/article.aspx?artid= $\underline{1452-94671601071 \mathrm{R}}$

14. Rivera, M., Croes, R., \& Lee, S. H. (2016). Tourism development and happiness: A residents' perspective. Journal of Destination Marketing \& Management, 5(1), 5-15. URL: https://www.sciencedirect.com/science/a rticle/pii/S2212571X15000219

15. Smith, T. G., Stillman, S., \& Craig, S. (2016). The US obesity epidemic: Evidence from the Economic Security Index. URL: https://www.otago.ac.nz/economics/otago 628299.pdf

16. Strezov, V., Evans, A., \& Evans, T. J. (2017). Assessment of the economic, social and environmental dimensions of the indicators for sustainable development. Sustainable

Development, 25(3), 242-253. URL: https://onlinelibrary.wiley.com/doi/abs/1 $\underline{0.1002 / \mathrm{sd} .1649}$

17. Toneva, P. I. (2017). Studying the impacts of event tourism on the host communities in Bulgaria. URL: https://essuir.sumdu.edu.ua/handle/1234 $\underline{56789 / 55513}$

18. Valdés, J. (2018). Arbitrariness in multidimensional energy security indicators. Ecological Economics, 145, 263273.

URL: https://www.sciencedirect.com/science/a rticle/pii/S0921800916312484 